\title{
PEMBANGUNAN SOSIAL DI WILAYAH PERBATASAN KAPUAS HULU, KALIMANTAN BARAT
}

\begin{tabular}{|c|c|c|}
\hline \multicolumn{3}{|c|}{$\begin{array}{c}\text { Luis Feneteruma } \\
\text { Pusat Penelitian Kemasyarakatan dan Kebudayaan - LIPI } \\
\text { lfenetruma@gmail.com }\end{array}$} \\
\hline 4 & Judul & $\begin{array}{l}\text { : Pembangunan Sosial di Wilayah Perbatasan } \\
\text { Kapuas Hulu, Kalimantan Barat }\end{array}$ \\
\hline & Penulis & : Henny Warsilah dan Dede Wardiat \\
\hline 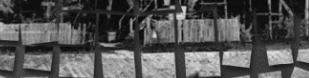 & Penerbit & : Yayasan Pustaka Obor Indonesia \\
\hline Pembangunan Sosial & Tebal & : xiv +190 halaman \\
\hline 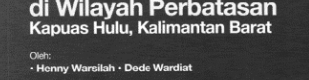 & Cetakan & : 2017 \\
\hline
\end{tabular}

\section{Pengantar}

Wilayah perbatasan antarnegara merupakan kawasan yang penting dalam menjaga sebuah kedaulatan negara yang harus mendapatkan perhatian penuh oleh pemerintah. Perbatasan adalah titik penting beranda sebuah negara yang seharusnya dikelola secara baik. Pada tahun 2014, Undang-Undang Desa dibuat dengan tujuan untuk memperkuat masyarakat desa sebagai subjek pembangunan dan meningkatkan pelayanan publik bagi warga masyarakat desa guna mempercepat perwujudan kesejahteraan umum. Mulai tahun 2015, pemerintahan Jokowi mengusung visi membangun dari pinggiran. Visi tersebut tertuang dalam program Nawacita,yang intinya adalah pembangunan difokuskan pada desa-desa dan daerah perbatasan. Program Nawacita tersebut memberikan bantuan dana langsung kepada setiap desa dalam rangka pembangunan fisik danpengelolaan sumber daya yang dimiliki. Dengan demikian, desa menjadi target pembangunan dalam lima tahun terakhir ini.

Dalam buku ini, penulis menjelaskan permasalahan dan memberikan solusi berupa konseppendekatan pembagunan sosial diwilayah perbatasan Kapuas Hulu, Kalimantan Barat. Pembangunan sosial tersebut bertujuan untuk membangun model sinergitas ruang fisik dan sosial untuk mendukung daya saing dan pemberdayaan masyarakat perbatasan. Adapun struktur buku ini terdiri dari enam bab yang dimulai dari sebuah prolog, dengan pembagian sebagai berikut. Bab pertama menjelaskan repositoring wilayah perbatasan. Bab kedua menjelaskan profil wilayah perbatasan.Bab ketiga mendeskripsikan pemanfaatan sumberdaya air untuk pangan di wilayah perbatasan. Bab keempat menjelaskan pemetaan sosial-budaya, ekonomi, dan ekologi wilayah perbatasan. Bab kelima mendeskripsikan pembangunan perdesaan sebagai sebuah strategi pengembangan wilayah perbatasan. Bab keenam membahas model sinergitas ruang fisik dan sosial untuk mendukung daya saing dan pemberdayaan masyarakat perbatasan.

Sebelum membahas lebih jauh buku ini, perlu untuk dipahami apa itu konsepsi pembangunan sosial. Pembangunan sosial berupaya mengangkat kesejahteraan rakyat dengan menggabungkannya dalam sebuah proses dinamis pengembangan ekonomi (Midgley, 2005). Pembangunan sosial menawarkan (a) Fokus pada perspektif makro yang komperhensif, bertitik pusat pada komunitas dan masyarakat; (b) Menekankan pada intervensi yang terencana; (c) Mengangkat pendekatan yang berorientasi pada perubahan yang bersifat dinamis, inklusif, dan universal; (d) Mengharmonisasikan intervensi sosial dengan usaha-usaha pembangunan ekonomi, serta (e) Menggabungkan tujuan-tujuan ekonomi dan sosial.

\section{Repositioning Wilayah Perbatasan}

Indonesia memiliki batas geografis wilayah yang bersinggungan langsung dengan sepuluh (10) negara tetangga, yang meliputi perbatasan di daratan dan perairan. Wilayah kontinen Republik Indonesia (RI) berbatasan langsung dengan Malaysia, Papua New Guinea (PNG), dan Timor Leste. Kawasan perbatasan 
kontinen tersebut tersebar di tiga pulau, empat provinsi, dan 15 kabupaten/kota. Masing-masing wilayah perbatasan memiliki karasteristik kawasan perbatasan yang berbeda-beda. Demikian pula negara yang menjadi tetangga langsung dengan Indonesia tersebut. Negara-negara itu memiliki karasteristik sosial, ekonomi, politik, dan budaya yang berbeda pula (hlm.13).

Pada bab pertama ini penulis menjelaskan tentang perkembangan perbatasan dan isu-isu sosial penting yang terjadi dibeberapa negara lainnya yang berbatasan. Isu-isu itu di antaranya adalah permasalahan air bersih -- atau yang biasa disebut dengan masalah ketahanan air, permasalahan pangan perbatasan, dan juga permasalahan penduduk miskin di daerah perbatasan. Meyangkut masalah air, ada banyak faktor penyebab kekeringan, antara lain eksploitasi sumber daya alam yang berlebihan dan lemahnya penegakan hukum.

Lebih lanjut,buku ini membahas mengenai konsep dan alur kerangka pikir serta metodologi yang dipakai dalam penelitian. Penulis menggunakan penelitian kualitatif dengan tujuan dari buku ini adalah sebagai policy paper model kebijakan sinergis tata ruang sosial dan fisik wilayah perbatasan antar-Negara yang memiliki daya saing, kemudian sebagai konsep pemberdayaan masyarakat dalam pengelolaan sumber daya air dan ketahanan pangan di daerah terpencil (perbatasan).

Buku ini memberikan solusi terhadap pendekatan pembangunan, menjelaskan bagaimana pengelolaan ketahanan air yang berkelanjutan dengan skema pembangunan sosial ketahanan air melalui pendekatan faktor struktur sosial, kultur dan proses sosial. Ada juga program pemberdayaan kepada masyarakat perbatasan baik itu wilayah perairan seperti danau maupun wilayah pertanian.

\section{Profil Wilayah Perbatasan Antarnegara}

Pada bab ini penulis menjelaskan tentang profil wilayah dan penggunaan lahan di Kabupaten Kapuas Hulu yang berbatasan langsung dengan Malaysia, dengan luas wilayah $31.162,87 \mathrm{~km}^{2}$ (3.116.287 ha). Batas wilayah antarnegaranya adalah sebagai berikut. Di sebelah utara: Malaysia, sebelah timur: Sarawak, Kalimantan Timur, dan Kalimantan Tengah, sebelah selatan: Kabupaten Sintang, sertasebelah barat: Kabupaten Sintang. Di daerah perbatasan tersebut terdapat enam kecamatan yang berbatasan langsung dengan Malaysia. Sebagian besar penduduk di wilayah perbatasan ini memiliki mata pencaharian di bidang pertanian. Mata pencaharian lain adalah di bidang perikanan, buruh, pedagang dan Pegawai Negeri Sipil (PNS). Namun, sebagian besar masyarakat di daerah Kapuas Hulu masih hidup dengan local wisdom dan bercocok tanam dengan sistem ladang berpindah-pindah, berburu, dan merambah hutan.

Salah satu contoh daerah perbatasan Indonesia-Malaysia yang dibahas di sini adalah Pulau Majang. Pulau Majang merupakan pulau yang berada di tengah Danau Sentarum, Kecamatan Badau. Masyarakat Pulau Majang menggantungkan hidup sehari-haridi danau dengan membuat tambak atau kolam ikan. Adapun jenis ikan yang di tambak adalah ikan tomang, ikan patin, dan ikan arwana.Namun, karena adanya pencemaran lingkungan, khususnya pencemaran air danau, menyebabkan penangkapan dan hasil budi daya masyarakat menurun. Tidak hanya pencemaran lingkungan, beberapa kendala lain yang dihadapi masyarakat Pulau Majang yaitu kurangnya kerja sama kelompok nelayan danau, penangkapan yang tidak ramah lingkungan oleh masyarakat, dan kurangnya sarana air bersih.

Permasalahan lain yang muncul adalah penggunaan lahan untuk tanaman kelapa sawit, rencana tata ruang Kalimantan Barat, serta kondisi existing sosial budaya wilayah perbatasan. Sesuai temuan lapangan, penulis buku ini menerangkanbahwa adanya pembabatan hutan dalam rangka penanaman kelapa sawit secara masif lah yang menyebabkan kelangkaan air di perbatasan Kapuas Hulu. Laporan dari Institut Dayakologi (2014) menyebutkan satu pohon kelapa sawit saja membutuhkan air sebanyak 8 liter per hari. Selain itu, tanah perkebunan kelapa sawit pada umumnya dalam kondisi miskin unsur hara, dan menjadi tidak subur jika ditanami tanaman lain, misal palawija dan sayuran(hlm.38).

Dalam penutup bab ini,penulis juga mendeskripsikankondisi masyarakat perbatasan Indonesia-Malaysia di tempat lain, yaitu masyarakat yang mendiami wilayah perbatasan Nanga-Badau. Baik etnik Dayak Iban maupun etnik Melayuyang tinggal di wilayah Indonesia masih dikategorikan sebagai masyarakat subsistem. Sementara itu, masyarakat Malaysia yang tinggal di daerah yang berbatasan dengan Indonesia 
sudah merupakan masyarakat modern dan berorientasi pasar. Dikotomi di kedua daerah perbatasan itu menjadi alasan penting bagi kita untuk irisannya sehingga memudahkan untuk melakukan pemberdayaan masyarakat perbatasan. Hal itu juga terkait dengan pengembangan masyarakat atau yang disebut dengan community development.

Terkait dengan pengembangan masyarakat, ada dua definisi yang bisa kita jadi rujukan. Pertama, konsep pengembangan menurut United Nation. Kedua, konsep pengembangan menurut Christenson. Pengembangan menurut United Nation adalah suatu proses yang didesain untuk menciptakan kondisi ekonomi dan kemajuan sosial untuk komunitas yang berhubungan dengan partisipasi aktif dan untuk memenuhi kemungkinan kepercayaan atas inisiatif komunitas. Komunitas sendiri ada dua, yaitu rural community dan urban community. Pengembangan adalah proses meningkatkan pilihan, dalam arti pilihan baru, diversifikasi, berpikir tentang isu secara berbeda dan mengantisipasi perubahan (Christenson, et. al., 1989).

\section{Pemanfaatan Sumber Daya Air untuk Masalah Pangan di Wilayah Perbatasan}

Pada babini, penulis menjelaskan tentang solusi bagaimana pemanfaatan sumber daya air untuk masalah pangan di wilayah perbatasan. Penulis memberikan data kebijakan dan fakta mengenai pentingnya ketersediaaan dan ketahanan air yang sangat mempengaruhi ketahanan pangan dan energi di masa depan. Jumlah penduduk bumi akan bertambah dan diperlukan sumber daya air untuk mendukung kehidupan manusia, flora, dan fauna. Oleh karena itu, sumber daya air perlu dikelola secara baik sehingga memenuhi kebutuhan pembangunan.

Data Kementerian PU menunjukkan bahwa potensi ketersediaan air di Indonesia ada sebesar 3,9 miliar $^{3}$ per tahun dan rata-rata $6000 \mathrm{~m}^{3}$ per kapita, sedangkan rasio kapasitas tampung masih rendah,artinya masyarakat kita sangat bergantung pada iklim. Ketersediaan dan ketahanan air akan sangat menentukan ketahanan pangan dan energi di masa depan. Terlebih-lebih, planet bumi ini sudah memikul beban populasi 7,3 miliar jiwa yang akan menjadi 9,5 miliar di tahun 2050 nanti (hlm. 46).

Sumber daya air sangat diperlukan untuk mendukung kehidupan manusia, flora, dan fauna. Oleh karena itu, sumber daya air perlu dikelola secara baik dan bijak, sehingga dapat digunakan untuk memenuhi kebutuhan pembangunan. Kekurangan air dapat menimbulkan kekeringan dan berdampak pada kehidupan spesies yang semakin rentan pada kesehatan, gagal panen, dan kepunahan. Di sisi lain, kelebihan air yang ekstrem dapat juga berdampak buruk pada kehidupan manusia, pertanian, dan spesies tertentu. Oleh karena itu, dibutuhkan pengelolaan sumber daya air yang tepat agar bisa menyeimbangkan penggunaan air.

Berkaitan dengan pengelolaan sumber daya air yang sangat penting diwilayah perbatasan, berikut beberapa rekomendasi yang diberikan oleh penulis yang penting untuk diterapkan. Pertama, pengelolaan secara alami. Kedua, kebijakan tata kelola air oleh negara-hal ini berkaitan langsung dengan optimalisasi Undang-Undang No. 7 Tahun 2004 tentang sumber daya air. Ketiga, tata kelola air oleh masyarakat. Poin ini mengarah pada meningkatkan berbagai upaya pemberdayaan masyarakat dalam pengamanan hutan dan vegetasi lingkungan untuk menghilangkan faktor penyebab menurunnya kuantitas sumber daya air disetiap daerah aliran sungai (DAS) yang ada. Keempat, kelembagaan irigasi.Kehadiran organisasi diperlukan untuk menjalankan fungsi-fungsi, mengatasi permasalahan yang disebabkan oleh konstruksi dan rehabilitasi yang dijalankan tidak rutin, mengatur alokasi air dan drainase, mengatur pemeliharaan irigasi, serta menangani konflik sosial yang timbul dalam pelaksanaan kegiatan-kegiatan yang berhubungan dengan pengelolaan persawahan.

\section{Pemetaan Sosial Budaya, Ekonomi, dan Ekologi Wilayah}

Bab ini memaparkan tentang kondisi Desa Badau yang merupakan desa yang berbatasan langsung dengan Malaysia. Penduduk Desa Badau pada tahun 2014 berjumlah 324.192 dengan pembagian laki-laki 120.786 dan perempuan 113.408. Berdasarkan hasil tinjauan lapangan yang disarikan dari laporan Gubernur Kalimantan Barat, permasalahan di daerah perbatasan Nanga-Badau terbagi ke dalam dua pendekatan, yaitu isu stragegis dan saran kebijakan. Dari situ diketahui ada empat isu strategis yang berkaitan dengan masalah di Nanga-Badau, yakni (1) Masalah ekonomi dan sosial budaya; (2) Minimnya ketersediaan prasarana dan sarana; (3) Rendahnya kualitas sumber daya manusia; serta (4) Pengelolaan sumber daya alam. 
Sementara itu, temuan permasalahan dan solusi berupa sektor yang dapat di kembangkan di perbatasan Nanga-Badau-Putussibau yang dikemukakan penulis adalah masalah infrastruktur, jalan, dan jarak tempuh, wilayah kerja Badan Nasional Pengelola Perbatasan (BNPP) yang bermasalah, serta masalah kondisi penduduk perbatasan. Selain itu, ada juga masalah pengembangan ekonomi kapitalis, seperti kelapa sawit dan perkebunan karet, pariwisata, dan budi daya ikan(hlm.72).

Meskipun demikian, selain memiliki beberapa masalah, wilayah perbatasan BadauPutussibau juga memiliki modalitas. Modalitas yang dimiliki oleh daerah perbatasan tersebut adalahSocial Capital, Human Capital, Nature Capital, dan Physical Capital.

Pada bab terakhirdibahas mengenai ketahanan pangan dan kesejahteraan penduduk daerah terpencil di perbatasan. Penulis menjelaskan bahwa Provinsi Kalimantan Barat memiliki potensi lahan pertanian yang cukup besar untuk tanaman pangan, yaitu sekitar lebih dari 1,2 juta ha. Saat ini, baru sekitar 546.594 Ha yang,secara fungsional, jika ditanami padi dua kali setahun akan diperoleh luas tanam/panen sekitar 1.000.000 ha.

Dalam menanggapi masalah-masalah di daerah perbatasan tersebut, pemerintah perlu melakukan suatu usaha menggerakan masyarakat untuk mengubah kehidupan mereka.Perubahan dalam masyarakat pada prinsipnya merupakan suatu proses yang terus menerus (Taneko, 1984:133). Artinya setiap masyarakat pada kenyataanya akan mengalami perubahan itu. Akan tetapi, perubahan antara masyarkat yang satu dengan yang lain tidak selalu sama.Ada masyarakat yang mengalami perubahan lebih cepat dibandingkan dengan masyarakat yang lainnya. Oleh karena itu, pemerintah perlu melakukan strategi perubahan yang disesuaikan dengan masing-masing daerah dan karakter masyarakatnya.

\section{Pembangunan Perdesaan: "Sebuah Strategi Pengembangan Wilayah Perbatasan"}

Selanjutnya, pada bab ini penulis menjelaskan pembangunan perdesaan, terutama mengenai strategi pengembangan wilayah perbatasan dengan melihat kondisi existing sebagai dasar untuk membuat kebijakankebijakan yang bisa mengangkat pertumbuhan ekonomi perbatasan. Berdasarkan hasil observasi dan penelitian penulis, ditemukan beberapa hal yang yang perlu diperhatikan dalam mengembangkan perdesaan. Salah satunya adalah dengan memperbaiki sarana dan prasarana seperti jalan untuk mendukung penjualan produk ke pasar. Hal ini penting diperhatikan karena selama ini jalan yang ada dalam keadaan tidak bagus sehingga masyarakat merasa kesulitan dalam melakukan penjualan produk.

Selain itu, pelatihan merupakan kebutuhan utama masyarakat perbatasan. Pelatihan di sini perlu dilakukan dengan tujuan agar masyarakat mampu meningkatkan dan memanfaatkan potensipotensi lokal yang mereka miliki. Selama ini, orientasi mereka hanya sebatas konsumsi pribadi. Oleh karena itu, diharapkan adanya pelatihan agar masyarakat memiliki manajemen bisnis dalam meningkatkan taraf hidup mereka. Selama ini, masalah di daerah perbatasan timbul karena faktor mendasar, yaitu mereka tidak memiliki pengetahuan.

Lebih lanjut, penulis memberikan masukan kepada pemerintah bahwa masalah pembangunan kawasan dan masyarakat perbatasan yang harus diselesaikan adalah sebagai berikut. Pertama, model kebijakan sinergitas perencanaan tata ruang sosial dan fisik wilayah perbatasan antarnegara yang memiliki daya saing. Kedua, konsep pemberdayaan masyarakat dalam pengelolaan sumber daya air dan ketahanan pangan di daerah terpencil (perbatasan), terutama di kawasan Danau Sentarum, melalui peningkatan daya saing produk unggulan.

Untuk menjawab permasalahan yang dikemukakan di atas, strategi yang dikembangkan adalah pemberdayaan masyarakat di perdesaan kawanan terpecil (perbatasan). Masyarakat perbatasan relatif tertutup, mempunyai keterikatan atau ketergantungan tinggi dengan alam, melakukan kegiatan produksi yang bersifat subsistem, dan memperoleh pelayanan sosial yang sangat minim. Hal itu menyebabkan tingkat kualitas sumber daya manusia (SDM) di daerah perbatasan yang relatif tidak terlalu tinggi. Namun, sebagian masyarakat perdesaan terpencil, khususnya masyarakat adat, mampu menghasilkan produk budaya yang berkualitas tinggi, seperti ukiran suku Dayak, pengelolaan hutan yang harmonis, dan sebagainya.

Oleh karena itu, pemberdayaan masyarakat, terutama di daerah perbatasan, membuka banyak kemungkinan, sebagai berikut. (1) Masyarakat perbatasan bisa bermukim secara menetap. (2) 
Adanya ekonomi pasar yang menguntungkan dan berkelanjutan dengan memperjualbelikan karet, kelapa sawit, padi, palawija, lada, serta budi daya ikan. (3) Adanya fasilitas sosial ekonomi, seperti sekolah, klinik kesehatan, listrik, dan air bersih.

(4) Masyarakat daerah perbatasan terhubung dengan angkutan darat/laut regular ke pusat desa/ kecamatan. Semua kemungkinan itu bisa diwujudkan dengan menerapkan sebuah strategi pembangunan yang tetap. Strategi tersebut, antara lain, dilakukan dengan penerapan pendekatan inklusi dan partisipasi, pemberian akses pada informasi, optimalisasi kapasitas organisasi lokal, dan peningkatan profesionalitas pelaku pemberdaya (hlm.109).

Berkaitan dengan pemberdayaan masyarakat, terutama di daerah perbatasan tersebut, ada dua pengertian dari pemberdayaan itu sendiri. Pengertian yang pertama adalah to give power or authority, pengertian kedua to give ability to or enable. Pemaknaan pengetian pertama meliputi memberikan kekuasaan serta mengalihkan kekuatan atau mendelegasikan otoritas kepada pihak yang kurang/belum berdaya. Sementara itu, pemaknaan pengertian kedua adalah memberikan kemampuan atau keberdayaan serta memberikan peluang kepada pihak lain untuk melakukan sesuatu (Prikono \& Pranarka, 1996: 77)

Dalam bab ini, penulis juga menjelasakan mengenai pemberdayaan masyarakat Pulau Majang yang tinggal diatas Danau Sentarum. Penjelasan mengenai pemberdayaan masyarakat Pulau Majang tersebut dilakukan dengan menjelaskan indikator ekonomi masyarakat, kondisi umum, mata pencaharian, isu dan tantangan, serta indikator sosial. Kemudian, penulis memberikan opsi pengelolaan bagi pemberdayaan masyarakat yang dimasukan dalam indikator kelembagaaan dengan skema kerangka kebijakan dan peraturan hukum. Skema tersebut diwujudkan dengan melakukan pengelolaan kolam berbasis komunitas organisasi wilayah Rukun Tetangga (RT) dan Model Kelembagaan Pra Koperasi pada tingkat dusun. Dalam mewujudkan skema di atas, prosesnya perlu dibagi ke dalam beberapa tahap sebagai berikut. Pertama, penguatan kapasitas masyarakat dan refoccusing opsi-opsi yang diusulkan. Kedua, pelaksanaan konsultasi, fasilitasi, dan pendampingan pembentukan kelembagaan lokal dalam skala sebagai pilot project. Ketiga, pelaksanaan monitoring dan evaluasi proses transformasi sosial dan konsekuensi yang ditimbulkan dari pemberdayaan penduduk Pulau
Majang. Keempat, pelaksanaan konsultasi dengan stakeholder dan pemerintah lokal dalam workshop atau FGD untuk memperbaiki program aksi yang dilakukan.

\section{Model Sinergitas Ruang Fisik dan Sosial untuk Mendukung Daya Saing dan Pemberdayaan Masyarakat Perbatasan}

Berdasarkan pemaparan dari bab-bab sebelumnya,maka di dalam bab terakhir buku ini penulis mengajukan model sinergitas ruang fisik dan sosial untuk mendukung daya saing dan pemberdayaan masyarakat perbatasan. Model tersebut dilaksanakan dengan solusi melalukan pemberdayaan masyarakat di Kapuas Hulu dalam bidang ketahanan air, perkebunan karet, tanaman lada, perikanan air, tanaman padi, kebun kelapa, peternakan, dan energi listrik. Pada prinsipnya, harus ada pemberdayaan dan fasilitas yang dilakukan oleh pemerintah baik pemerintah pusat maupun daerah.

Lebih lanjut, disebutkan bahwa pemberdayaan masyarakat Badau-Puttusibau bisa dilaksanakan dengan membangun sarana prasarana jalan, membangun pembangkit listrik berbasis MikroHidro, serta memberikan keterampilan dalam budi daya ikan kepada masyarakatnya. Selain itu, pemberdayaan masyarakat bisa juga diwujudkan dalam bentukperkebunan rakyat. Hal tersebut dilaksanakan dengan cara melakukan pengembangan pangan pokok non-beras, seperti jagung, singkong, ubi, pisang, talas, dan lainnya. Selain itu, daerah perbatasan Nanga-Badau membutuhkan pasokan listrik untuk digunakan masyarakatnya dalam melakukan kegiatan sehari-hari. Hal itu bisa ditanggapi dengan membangun pembangkit listrik Mikro-Hidro tenaga solar.

Begitu juga yang terjadi di Pulau Majang. Di Pulau Majang terjadi krisis air danau dan hilangnya habitat ikan yang menyebabkan krisis pangan dan kehilangan mata pencaharian. Oleh karena itu, penulis memberikan konsep model yang bisa dilakukan dengan menerapkan model pengelolaan danau secara terpadu, memberikan pelatihan berupa kemampuan budi daya ikan kepada masyarakat atau kelompok nelayan, serta membangun kelembagaan pengelolaan danau.

Terakhir adalah pemberdayaan usaha kolektif di Danau Sentarum, Kapuas Hulu. Pemberdayaan di Danau Sentarum dapat dilakukan dengan membangunsuatu kelembagaan yang dapat mengatur nelayan dengan pembentukan 
koperasi atau Badan Layanan Umum (BLU). Lembaga tersebut nantinya bekerja untuk mengelola sistem pengelolaan ikan. Adapun kegiatan yang diusulkan penulis dalam membangun pembedayaan masyarakat Danau Sentarum adalah sebagai berikut. Pertama, survei/ mapping. Kedua, melakukan riset aksi kegiatan pembibitan ikan rakyat. Ketiga, pengembangan demplot budidaya ikan. Keempat, mengembangkan kapasitas kelembagaan pemanfaatan danau.

\section{Penutup}

Buku ini sangat menarik karena ditulis berdasarkan temuan lapangan. Melalui buku ini, pembaca dapat memahami permasalahan-permasalahan yang terjadi di daerah perbatasanselama ini. Penulis buku initidak hanya memetakan masalah saja tetapi juga memberikan solusi-solusi dan konsep pembangunan, sehingga dapat membantu pemerintah dalam mebuat kebijakan dan program di daerah perbatasan.Pembahasan dalam setiap bab dijelaskan dengan baik meskipun tidak dijelaskan berapa besar penganggaran yang telah lontarkan pemerintah, baik pusat (APBN) maupun daerah (APBD), dalam rangka mengatasi permasalahan perbatasan di Kapuas Hulu.

Buku ini sangat disarankan untuk dibaca oleh peneliti atau orang-orang yang tertarik dengan kajian desa tertinggal ataupun kajian wilayah perbatasan dan ilmu sosial.Buku ini bisa membantu pembaca dalam melihat pemetaan permasalahan lapangan dan pendekatan-pendekatan yang digunakan dalam mengahdapi masalahmasalah di daerah perbatasan tersebut. Untuk memahami lebih jauh mengenai permasalahan yang dijadikan contoh dalam buku ini, pembaca dapat juga membaca buku Daron Acemoglu dan James A. Robinson yang berjudul Mengapa Negara Gagal (Awal Mula Kekuasaan, Kemakmuran,dan Kemiskinan) yang diterbitkan oleh Kompas Gramedia.

Apabila pembaca ingin mengetahui isuisu pembangunan daerah yang sekarang sedang berkembang, buku ini sangat tepat untuk dibaca karena mengangkat konsep pemberdayaan masyarakat dan pembangunan sosial. Perspektif penulis dalam membedah permasalahan di buku ini begitu terstruktur dan memberikan solusi yang tepat, baik dari sisi pembangunan sarana prasanana maupun pemberdayaan masyarakat dalam meningkatkan sumber daya manusia.

\section{Daftar Pustaka}

Christenson, J.A. and Robinson, J.W. (1989). Community Develompment in Perspective. Iowa State University Press, Ames Iowa.

Midgley, James. (2005). “Pembangunan Sosial Perspektif Pembangunan dalam Kesejahteraan Sosial.” Direktoran Perguruan Tinggi Adama Islam Depag RI. Jakarta.

Prijono, OS., Pranarka, A.M.W. (1996). Pemberdayaan: Konsep, Kebijakan dan Implementasi. CSIC. Jakarta.

Soleman B. Taneko, (1984). Struktur dan Proses Sosial Suatu Pengantar Sosiologi Pembangunan, CV. Rajawali, Jakarta. 